\title{
STATIC AND DYNAMIC STATES: THE CASE OF ESTONIAN STATIVE COLOUR EXPRESSIONS
}

\author{
Geda Paulsen \\ Institute of the Estonian Language
}

\begin{abstract}
The aim of this study is to account for stative situations through the example of structurally different but semantically close colour expressions: the Estonian stative verbs derived from colour adjectives and colour adjectives appearing as the predicative. Stative verbs are assumed to be similar to copula constructions, with the aspectual distinction of temporary/permanent property. In this article, the stative colour expressions are analysed using the linguistic diagnostics developed for the determination of ontological properties of different types of states - the sc. Davidsonian and Kimian states (see e.g. Maienborn 2003). Analysis reveals that the copula construction with colour adjective as predicative is ambiguous, inclining to the Kimian states but also assigning properties characteristic to the Davidsonian states; the stative colour verbs, in turn, are true examples of Davidsonian states. In addition to the examination of the stative properties, the conceptual structure analysis of the colour expressions instantiating stative and dynamic states is given. The observer's evaluation of the coloured object as a mental image is treated as part of the lexical information of the colour statives. Also, sentential and contextual phenomena of the colour statives are discussed.
\end{abstract}

Keywords: stative colour verbs, copula construction, event structure, conceptual semantics, Estonian

\section{Introduction}

In most languages, colour terms are encoded as adjectives; colour is, according to Dixon (2004: 3-4), one of the four basic types of adjectives, the others being dimension (e.g. big and small), age (e.g. new and old) and value (e.g. good and bad). Most colour term studies, both language-specific and crosslinguistic, have been focused on adjectives, with the influential 
study of Berlin and Kay (1969) being central. Estonian is one of the languages that lexicalise property concepts also as verbs. Three verbal types derived from colour adjectives can be distinguished: statives, inchoatives and causatives. The present study focuses on two formally different but semantically close colour expressions: intransitive stative verbs and copular constructions. As these non-dynamic and non-agentive structures correspond to basically stative features, these will be contrasted to the ontological properties of statives as formulated by Maienborn (2003, 2005a, 2005b, 2007).

The colour statives discussed in this article are derived from colour adjectives that correspond to the basic colour terms in Estonian, as defined by Sutrop $(1995,2000)$. The stative colour verbs can be formed either by conversion (with only conjugation markers added to the colour stem, as in valge 'white' $<$ valka-ma [white-inf] 'to appear white') or by suffixal derivation with the verbal suffix $t a / d a^{1}$. The Estonian colour statives derived from basic colour terms are presented in Table 1. It appears that nine of eleven colour terms in Estonian have stative derivatives. Six basic colour terms have parallel stative variants attested to the Explanatory Dictionary of Estonian (EKSS); the three remaining colour terms, hall 'grey', lilla 'purple' and roo$s a$ 'pink' have one stative variant each. Note that there are no stative verb equivalents for Estonian basic colour terms oranž 'orange' or pruun 'brown'.

The translations of colour statives reveal the twofold nature of these verbs: they are defined in the EKSS by a paraphrase using the verb olema 'be' ('to be of the colour') or paistma 'appear' ('to be seen by the colour'), for instance olema punane 'be red' or paistma punane 'appear red'. Interestingly, only the verb valendama is defined in EKSS using only 'appear white'. Why is there such a dichotomy and is this characteristic to all stative colour expressions? How does the ambiguous character affect the eventive features of colour statives?

1 The verbal suffix variations around the element $-t a$ are, according to EKG I (429-439), the following: -ta-, -da-, -sta-, -nda-, -lda-, -rda- and -t-, and these are classified as causative and factitive suffixes. 
Table 1. Estonian colour statives derived from basic colour terms.

\begin{tabular}{|l|l|l|}
\hline valge $^{2}$ 'white' & $\begin{array}{l}\text { vale- } n \text { - } d a-m a \\
\text { valka-ma }\end{array}$ & 'to appear white' \\
\hline must 'black' & $\begin{array}{l}\text { muste-n-da-ma } \\
\text { musta-ma }\end{array}$ & 'to be black, to appear black' \\
\hline punane 'red' & $\begin{array}{l}\text { puna-ma } \\
\text { pune-r-da-ma } \\
\text { pune-ta-ma }\end{array}$ & 'to be red, to appear red' \\
\hline kollane 'yellow' & $\begin{array}{l}\text { kolle- } n-d a-m a \\
\text { kolle-ta-ma }\end{array}$ & 'to be yellow, to appear yellow' \\
\hline roheline 'green' & $\begin{array}{l}\text { rohe-ta-ma } \\
\text { rohe- } n-d a-m a\end{array}$ & 'to be green, to appear green' \\
\hline sinine 'blue' & $\begin{array}{l}\text { sina- } m a \\
\text { sine- } n-d a-m a \\
\text { sine-r- } d a-m a\end{array}$ & 'to be blue, to appear blue' \\
\hline pruun 'brown' & & \\
\hline hall 'grey' & halle- $n-d a-m a$ & 'to be grey, to appear grey' \\
\hline lilla 'purple' & lilla-ta-ma & 'to be purple, to appear purple' \\
\hline oranž 'orange' & & \\
\hline roosa 'pink' & roosa-ta-ma & 'to be pink, to appear pink' \\
\hline
\end{tabular}

In an attempt to elucidate the nature of colour state expressions, I will start with an examination of the notion of stat(iv)es in Section 2. Recent research on event structure, in particular on the class of statives, is based especially on the works of Maienborn (2003, 2005a, 2005b, 2007). In Section 3, stative verbs are compared to copular constructions, with a colour adjective as predicative (as in Mets on roheline 'The forest is green'). Linguistic diagnostics designed for the differentiation of different types of states (see e.g. Maienborn 2005b) will be applied to stative colour expressions in Section 3.2. I will give a conceptual semantics analysis of the colour states in Section 4. The distinction of 'being of a colour' and 'appearing in a colour' will be

2 According to Koski (1983), there is a stem pair with and without $k$, valkV and valV, from the Early Proto-Finnic language, corresponding to valge 'white'. 
discussed in connection with the observer's perspective on the coloured object in Section 4.2. Section 5 is devoted to the colour states and existential clause type, and Section 6 presents some notes on the case of stative verbs derived from punane 'red' and structural surroundings they appear in.

The material illustrating this study was retrieved from The Balanced Corpus ${ }^{3}$, one of the subcorpora of the Corpus of Written Estonian, compiled at the University of Tartu. The material of The Balanced Corpus of Estonian represents the three main text classes of the written language from 1890-1990: fiction, journalistic and scientific writing.

\section{Static and dynamic states}

Since the present study focuses on stative expressions, I will start with a short overview of the classification of stative situations. In the following discussion, the term situation is used as a generic term ${ }^{4}$ covering the more specific situation types, such as states, events and processes. The term event corresponds to Bach's (1986) notion of eventuality, which is a cover term for events (accomplishments and achievements in Vendler's (1967) terms), processes (Vendler's activities) and certain (Davidsonian) states.

The question of event structure conceptualisation and how it is reflected in grammar has preoccupied linguists and philosophers, especially in the last half century. The notion of stative predications and states is, however, still not completely clear within linguistic literature. In general, states are opposed to events: whereas events involve a temporal dimension, states do not refer to any kind of time structure (Jackendoff 1990, and Nikanne 1990:15-16). The pioneering work on the segregation of the event structure of verbs ${ }^{5}$ is Vendler's (1967) article Verbs and times.

3 http://www.cl.ut.ee/korpused/grammatikakorpus/ (14.02.2012)

4 Some of the covering terms in use are Dik's (1978) state of affairs and Pustejovsky's (1991) event structure.

5 As Rothmayr (2009: 35) notes, there are three other main kinds of stative structures, or stativizers, apart from stative verbs: generic sentences, perfect constructions and the adjectival passive. 
His definition of statives is based on the temporal proceeding of events: state verbs are agentless verbs (in contrast to activity verbs) without any endpoint in their basic meaning (e.g. know, love). However, it has turned out that statives comprise a rather heterogeneous set of verbs. Dowty (1979: 180) points to a fundamental distinction within stative verbs: verbs of position (e.g. sit and lie) take the progressive form ( $X$ is sitting) in English, while other statives cannot ${ }^{6}$. Bach (1986) concurs with this idea and distinguishes two types of statives, dynamic and static statives: the verbs of the first group are sit, stand and lie, in combination with a location modifier, and the second group includes such expressions/words as be drunk, be in New York, own, love and resemble.

The theory of a split class of statives is developed further in Maienborn (2003, 2005a-b, 2007) and Rothmayr (2009), based to a great extent on the ideas of Davidson (1967). The Davidsonian account of adverbial modification, originally used with action verbs, has proved to be useful in the separation of the ontological properties of situation types. Davidson argues that adverbials are anchored in an event argument that must consequently be present in the structure of (eventive) verbs. Since statives do not allow for these adverbials, they are assumed to lack this argument, referred to as the Davidsonian argument. Maienborn's $(2003,2005 a-b, 2007)$ theory of nondynamic expressions distinguishes between state verbs (sleep, sit, stand, lie and wait), ${ }^{7}$ corresponding to the criteria for sc. Davidsonian eventualities, and stative verbs (know, weigh, own and resemble), which meet the Kimian state criteria. The latter group includes copular constructions, regardless of whether they are stage-level predicates (denoting a temporary property) or individual-level predicates (conveying a more or less constant property). Kimian states reflect Kim's (1969) notion of

6 Statives are generally assumed to inhibit the progressive form (see e.g. Lyons 1977: 707).

7 Dowty (1976) argues that the crucial difference between processes and states is related to their subinterval properties: processes consist of several subintervals of the same type (e.g. run, breathe and glitter) but states encode no subintervals. Therefore, such verbs as wait, sleep, sit and hang are categorised as states. 
temporally bound property exemplifications - they are not perceptible, and they cannot be modified by event-related adverbials (Maienborn (2007)). Davidsonian states, in turn, allow for all of those relations.

In her investigation of statives, Rothmayr (2009) notes that the nature of stative verbs has not yet been fully expounded, but four assumptions about statives can be specified (ibid. 39):

- Stative predicates are the smallest and simplest buildingblocks of event structure.

- Stative verbs have a less complex structure than eventive verbs.

- Stative verbs are very similar to copular constructions.

- Stative verbs contain only a single (structural) argument, which is the holder of the state.

Rothmayr's study questions the general assumptions about statives. Having the distinction between Kimian and Davidsonian statives (cf. Maienborn 2003) as a starting point, the results of her examination of different type of stative verbs suggest that they cannot be seen as the smallest building-blocks of event structure. It is possible for a verb to express both a state and an event (either by containing an intentional activity by an agent, or by expressing a change of state), and hence the event structure must be a property of the lexical-semantic structure of stative predicates in a verb. Rothmayr ends up with a division of stative verbs into two main groups: 1) verbs that allow stative reading only (subject-experiencer verbs, such as love, and verbs of position) and 2) verbs that display systematic stative-eventive ambiguity (e.g. verbs with both a causative and stative reading, such as obstruct, dispositional verbs, such as help, verbs with a modal operator and a feature of action, such as threaten, and verbs of body posture). The explanation for the stative/eventive ambiguity is, according to Rothmayr, a cause-operator in a verb's semantic structure that relates two sub-eventualities to one another; the stative interpretation arises when both subeventualities are stative. 
Is there causality involved in the colour statives, for instance in relation to the factor that brings about the appearance of an object in a certain colour? What kind of state expressions are they? There are several diagnostic tests for the evaluation of the ontological properties of states. I will apply these tests on the Estonian colour statives in Section 3.2. Since copular constructions are the exponents of the stative category and the similarity of stative verbs to copular constructions has been ascertained, the corresponding colour predicate propositions are included in the examination. What do these tests reveal about the colour expressions in question? Do the copular construction of a colour predicative and the stative colour verb construction represent static and/or dynamic states in Bach's terms? Before a closer exploration of these questions, I will give a short overview of the stative colour expressions in Estonian.

\section{The stative colour predications in Estonian: states or events?}

\subsection{On the background of Estonian colour states}

In Estonian, the state of an object having a property of colour can be expressed both using a copula complement as in (1) and an intransitive predicate, a stative colour verb (2). In both cases the subject argument bears the thematic role theme, corresponding to the object being coloured. This is also the only referential argument in (1) and (2).

(1) Kuu on kollane. moon be-3SG yellow 'The moon is yellow'

(2) Kuu kollendab. moon yellow-ST-3SG 'The moon casts a yellowy light'

A common way to analyse the derivative propositions within the Estonian word formation tradition is the specification 
of paraphrase types reflecting the underlying structure of the derivative. This method is used by Kasik (1996), who describes the stative denominal verbs or status derivatives (the term she uses in this paper is olemisverbid 'the verbs of being' because of the paraphrase type) using the copula-paraphrase. The example Kuu on kollane 'The moon is yellow' presented in (1) is, according to this approach, a paraphrase of the example Kuu kollendab 'The moon casts a yellowy light' (2).

However, as the translation of these examples indicates, the semantics of the predicative clause and the stative verb clause are not identical. A distinction based on the temporary-constant opposition can be made: while the copula proposition expresses a rather stable property of the coloured object, the stative colour verb proposition indicates a non-persistent property. This characterises, according to Kasik (1996: 16), the deadjectival statives in general: they refer to temporary, not inherent characteristic properties. Hence, we can say: Sidrun on kollane 'The lemon is yellow', because lemons are yellow by nature and Kaselehed kollendavad 'The birch leaves appear yellow', as birch leaves are not constantly yellow.

The aspectual distinction between copula construction and stative verb is, however, not completely obvious. Our world knowledge indicates that lemons similarly to birch leaves are green at the beginning. Consider the example (3), taken from the corpus material. This example contains both types of colour expressions, but the temporary-constant distinction is not straightforward here: the predicative construction with the colour helesinine 'light-blue' does not mean that it is the constant property of the sky, which is similar to the stative colour verb punetama 'appear red' referring to the reddish colour on the rowan berries (or the rowan tree's leaves) at a particular moment of time.

(3) Taevas on helesinineja minuaknataga punetavad pihlakad

The sky is light-blue and outside my window red-ST-3PL rowans 
Kasik (1996: 16) argues that the temporary nature of the property conveyed by the stative verb anchors it to the speech moment. Maienborn (2005a), analysing the stage-level/individual-level distinction of the copular constructions, argues that this difference is due to discourse structure rather than the inherent property of the predicates. The stative colour verb punetama 'appear red' in (3) thus refers to the state at a particular moment and the copula construction of 'the sky being blue' presents the situation as a constant or relatively more constant property of the sky. The temporary-characteristic distinction is naturally not connected directly to the "real world" but reflects the way the speaker presents reality. Example (1), hence, expressing the visual property of the theme argument ( $k u u$ 'moon') by the predicate adjective refers to a characteristic property (the moon being yellow). In (2), the colour property indicated by the verb kollendama 'to appear yellow' has a temporary nature - the moon is being seen in a yellow colour at the moment of expression.

We can compare the special temporal nature of colour statives to a similar situation in Finnish. Koski (1983: 286) argues that the Finnish stative deadjectival verbs ${ }^{8}$ do not change the denotation of the corresponding copula clause with the adjective root, but that there is an aspectual difference: if the adjective is referring to a basically static property, the copula construction refers to a state ( $Y$ on punainen ' $Y$ is red') and the stative verb ( $Y$ punoittaa ' $\mathrm{Y}$ appears red') turns the state into a process. Thus, by saying $Y$ punoittaa ' $\mathrm{Y}$ appears red' the speaker regards the situation as if the referent of $Y$ is "acting" in a way that it obtains the impression of the reddish colour. However, Pennanen (1978) notes the ambiguity of the Finnish stative colour verbs displaying the concurrently stative and dynamic characteristics (ibid. 148, 150):

"... they have a feature of permanence or continuity: to be red, blue etc. means continually so. But at the same time there is

8 The term Koski uses for stative denominal verbs is essentiaalinen verbi 'essential verb', which is the common practice within Finnish word formation research. 
also a dynamic element in them, describable as an optical scintillation, e.g. the sparkling white of the snow on a sunny day (oddly enough there is no essential verb meaning 'to be white $\left.{ }^{9}\right)$. Similarly, a colour verb may admit of interpretation as denoting a process, so slow as to give the impression of stativity at the same time, for example harmahtaa 'to be grey, have a greyish tinge' but also 'to turn grey'."

Do the colour statives include both static and dynamic features or is there a functional distribution between the predicative colour construction and colour statives? When it comes to the properties of these stative expressions, does the copula construction correspond to Kimian states and the colour statives to Davidsonian states? I will take the assumption of ontologically different kinds of eventualities argued for in Maienborn (2003, 2007) and Rothmayr (2007) as a starting point and apply the linguistic diagnostics developed for the distinction of these situations for the analysis of the stative properties on the expressions in question in the next section.

\section{2 "Eventuality diagnostics" and stative colour expressions}

Maienborn $(2003,2005 b, 2007)$ argues that there are two kinds of non-dynamic expressions, corresponding to Davidsonian states and Kimian states. The linguistic diagnostic necessary to distinguish them is based on the idea that, in contrast to Davidsonian states, Kimian states are not perceptible and they cannot be modified by event-related adverbials (recall the discussion in Section 2); Davidsonian states, in turn, are particular spatiotemporal entities with functionally integrated participants. Like Davidsonian states, Kimian states are available to ana-

9 For a comparison, there are two stative verbs formed from valge 'white' in Estonian, valendama and valkama. Also black has no statives in Finnish, but in Estonian it relates to two derivatives, mustendama and mustama, denoting 'to appear black'. 
phoric reference and time modification. Thus, although more restricted than the Davidsonian argument, also Kimian states can be argued to introduce an underlying event argument that can be located in time and may serve as an antecedent for anaphoric reference. This gives rise to the following linguistic diagnostics for Kimian states, quoting Maienborn (2007: 111):

a. Kimian state expressions cannot serve as infinitival complements of perception verbs and do not combine with locative modifiers.

b. Kimian state expressions are accessible for anaphoric reference.

c. Kimian state expressions combine with temporal modifiers.

The linguistic diagnostics for Davidsonian states adds the property of free combination with adverbial phrases (ibid. 109):

a. Eventuality expressions (i.e. Davidsonian states, GP.) can serve as infinitival complements of perception verbs.

b. Eventuality expressions combine with locative and temporal modifiers.

c. Eventuality expressions combine with manner adverbials, instrumentals, comitatives etc.

I will start with the infinitival complement test of perception verbs, which can, in the case of Estonian colour states, be carried out using the verb nägema 'see' and the inessive mainfinitive or supine form, typically conveying the sense of 'being in a process'. Examples (4a-b) illustrate the perception report of the copula construction and the stative verb, respectively; the copular construction fails the infinitival complement test of nägema 'see' and the stative colour verb passes it:

(4) a. *Ma nägin kuud kollane olemas.

I saw moon yellow be-SUP-INE

b. Ma nägin kuud kollendamas.

I saw moon yellow-ST-SUP-INE 
In connection with perception verbs, the infinitive form -vat is regarded as being synonymous with the mas-supine (EKG II 249) (see (4c-d)), in both cases meaning roughly 'I saw the moon being yellow' Interestingly, the -vat form seems to combine slightly better with the copula construction than -mas; the stative verb assigns also -vat form unambiguously in the perception report construction (cf. the examples (4a) and (4d)):

(4c) ?Ma nägin kuud kollane olevat

I saw moon yellow be-INF

(4d) Ma nägin kuud kollendavat

I saw moon yellow-ST-INF

Since the perception verbs function as object-raising verbs, it would be interesting to see if this test also works with a subordinate clause ${ }^{10}$ and separates "true" statives from ambiguous statives. In contrast to the infinitival complement test, both colour expressions pass this test (see 5a-b). All in all, the colour stative expressions may be exceptional regarding the perception report tests: colour is a property based on visual perception. Hence, the combination of colour statives with other perception verbs, such as kuulma 'hear' or maitsma 'taste' is not possible (unless the verb kuulma 'hear' is used as a 'reported speech verb").

(5) a. Ma nägin, et kuu oli kollane.

I saw that moon was yellow

b. Ma nägin, et kuu kollendas.

I saw that moon yellow-ST-PAST-3SG

The Davidsonian states are assumed to take locative modifiers, whereas the Kimian states do not combine with locatives. As Maienborn $(2003,2005 a)$ points out, it is important here to distinct between VP-modifiers and sentential modifiers, since the event-external spatial modifiers do not relate to an underly-

10 I thank Heete Sahkai for pointing this out to me. 
ing eventuality argument but provide a semantically underspecified domain restriction for the overall proposition. In order to avoid a temporal frame-setter analysis of locatives, Maienborn (2003: 173) suggests that an additional temporal adverbial can be used in the locative modifier tests. Both colour predicative and colour stative constructions enable locative modification, see examples (6a-b):

(6) a. Kuu on (juba) kollane metsa kohal/ taevas/tumeda pilve kõrval. The moon is (already) yellow over the forest/ in the sky/by the dark cloud.

b. Kuu kollendab (just nü̈d) metsa kohall taevas/tumeda pilve kõrval. Moon yellow-ST-3SG (right now) over the forest/ in the sky/by the dark cloud.

Statives are assumed to be subject to a particular kind of anaphoric reference, where the anaphoric pronoun refers back to a state. Both the copula construction (7a) and the colour stative verb (7b) pass the anaphoric reference test; the Estonian anaphoric pronoun see 'this' refers back to the state described by the colour expression:

(7) a. Kuu on kollane. See kestab tund aega. Moon is yellow. This lasts for an hour. b. Kuu kollendab. See möödub peagi. Moon yellow-3SG. This will be over soon.

Both expressions allow for the eventuality test of combination with temporal modifiers, as illustrated in (8). I add to the purely temporal adverbials the degree-modifier test suggested by Maienborn (2003: 176-178), modifying the temporal extension of the situation with the adverb a little, in Estonian natuke. The degree adverbial allows for a temporal interpretation only when the verb expresses an event; Kimian states are restricted to degree readings. This modifier seems to denote the degree of 
the colour rather than time in the case of a copula construction. A resultative temporal modifier, such as tunniga 'in an hour' cannot be combined with either construction, for the reason that there is no change involved in both expressions.

(8) a. Kun on alati/terve öö/jälle/natukel

*tunniga kollane.

The moon is always/the whole night/again/a little/ in an hour yellow.

b. Kuи kollendas alati/terve öö/ jälle/natuke/*tunniga.

The moon yellow-ST-3SG always/the whole night/ again/a little/in an hour.

Davidsonian states are assumed to combine freely with manner adverbials and comitatives (i.e. modifiers that elaborate the internal functional structure of eventualities), while Kimian states do not (Maienborn 2007:109-110). Examples (9a-b) show that suitable manner adverbials occur both with the colour predicative construction and the stative colour verbs. There is a difference in how these structures relate to the comitative modifier: the copula construction does not allow it, whereas it is completely natural with the stative verb.

(9) a. Kun on eredalt/silmatorkavalt/üleni/ *koos pilvedega kollane.

The moon is vividly/conspicuously/entirely/ with the clouds yellow.

b. Kun kollendab eredalt/silmatorkavalt/ üleni/koos pilvedega.

The moon yellow-ST-3SG vividly/conspicuously/ entirely/with the clouds.

After implementing the diagnostic tests for Kimian and Davidsonian states on the colour expressions, the results are summarized in Table 2. The capital D in the table indicates that the construction in question passes the particular Davidsonian 
state test and $\mathrm{K}$ stands for a correspondence to Kimian state properties in regard to the linguistic diagnostics in question. I have separated the comitative test from the manner adverbial test, since there was a clear difference in acceptance of the comitative adverbial between the copula construction and stative verb. Recall that both states types allow for anaphoric reference and time modification, hence, these tests do not display distinguishing properties between Kimian and Davidsonian states. Therefore, the notation $\mathrm{D} / \mathrm{K}$ in Table 2 stands for shared attributes.

Table 2. The results of the eventuality tests.

\begin{tabular}{|c|c|c|c|c|c|c|}
\hline & $\begin{array}{c}\text { Percep- } \\
\text { tion } \\
\text { verb + } \\
\text { inf } \\
\text { tive } \\
\text { modi- } \\
\text { fier }\end{array}$ & $\begin{array}{c}\text { Loca- } \\
\text { phoric } \\
\text { refer- } \\
\text { ence }\end{array}$ & $\begin{array}{c}\text { Tem- } \\
\text { poral } \\
\text { modi- } \\
\text { fier+ } \\
\text { degree } \\
\text { advl }\end{array}$ & $\begin{array}{c}\text { Manner } \\
\text { adver- } \\
\text { bial }\end{array}$ & $\begin{array}{c}\text { Comita- } \\
\text { tive }\end{array}$ \\
\hline $\begin{array}{c}\text { Colour } \\
\text { predi- } \\
\text { cate con- } \\
\text { struction }\end{array}$ & $\mathrm{K}$ & $\mathrm{D}$ & $\mathrm{D} / \mathrm{K}$ & $\mathrm{D} / \mathrm{K}$ & $\mathrm{D}$ & $\mathrm{K}$ \\
\hline $\begin{array}{c}\text { Colour } \\
\text { stative } \\
\text { verb }\end{array}$ & $\mathrm{D}$ & $\mathrm{D}$ & $\mathrm{D} / \mathrm{K}$ & $\mathrm{D} / \mathrm{K}$ & $\mathrm{D}$ & $\mathrm{D}$ \\
\hline
\end{tabular}

We can conclude that the distribution of stative properties is not completely straightforward. The colour predicate construction corresponds partially to the Davidsonian state properties and partially to the Kimian state symptoms. The colour stative displays prominently Davidsonian state indications. The locative and manner modifier tests show that the colour copula construction combines quite freely with different types of adverbials. Why is this so? A feature of colour expressions is that they are perceptible by nature; even more, this is their central semantic characteristic. The theme argument specifies the location of the perceived colour and the theme is itself part 
of a background, corresponding to a prototypical figure-ground opposition.

The examined colour expressions differ clearly in the perception report test (see (4)), suggesting that the copula construction with the colour adjective can be classified as a stative state and the colour stative verb as a dynamic state in Bach's terms. Importantly, the supine form -mas (the form of the complement in the perception verb construction) is in combination with the verb olema 'be' regarded as the Estonian progressive, expressing an ongoing process (see Metslang 1993, Erelt 2003: 105). This meaning is there also in the perception verb test, together with a focus on the particular time of sensation. Metslang (1993: 410411) regards the verbs inhibiting the progressive construction as true statives and suggests that the static verbs allowing the progressive are either statives with an ambiguous status in relation to the static-dynamic division or stative verbs that permit the dynamic sense. It is apparent that the copula colour construction does not allow the progressive form (*Kuи on kollane olemas 'The moon is being yellow'), whereas the colour stative does not hinder the progressive (Kuи on kollendamas 'The moon is casting a yellowy light'), which strengthens the different status of the stative colour expressions. Hence, this quality shows a fundamental divergence between the stative colour expressions.

The different behaviour of studied expressions in the perception report test may be related to the temporary-constant opposition these constructions display (recall the discussion in Section 3.1): the constant, characteristic property yields rather generic sentences and the temporary feature is connected to the particular time of utterance, as in the case of the perception report. A connection to generic utterances can here be pointed out. Note that colour predicates can be used in the generic sense, for example Apelsinid on (alati) oranžid 'Oranges are (always) orange' (note also that the locative modification in the generic sense is incorrect *Apelsinid on (alati) oranžid laual 'Oranges are (always) orange on the table'). In contrast, the colour statives do not adapt naturally to the generic sense: ?Sidrunid alati kollendavad 'Lemons always appear yellow'. This could be a 
further linguistic diagnostic for the distinction of these state expressions.

Another test that gave different results is the comitative modifier test that shows a restricted ability in the modification combination of the copula constructions. Is this also due to the durativity-feature? Recall example (9a); whereas the yellowness of the moon can be seen as a characteristic feature, the yellowness of clouds is a rather exceptional occurrence, which does not correlate with the semantics of the copula construction.

The manner modification test can, in fact, not be regarded as a completely clear distinguisher of different types of states. In connection to stative expressions, manner modification may display a special licensing course: Maienborn $(2003,2007)$ argues that, due to event coercion, states may in the course of a reinterpretation process insert a non-compositional event into the structure of the stative verb. This "created event" then serves as the anchor for the contribution of the manner adverbials. In Maienborn's (2007:117) words:

The basic idea is that such event coercion takes as presuppositions the sortal requirements of a modifier that conflict with the modifier's compositionally designated target and, if possible, accommodates these requirements by introducing a new event referent into the universe of discourse.

There is thus a link to the discourse that turns a state into an event. The reinterpretation process described above is clearly dependent on world knowledge, relying on a connection to pragmatic contextual knowledge. For this reason, sentence (10a) is acceptable and (10b) is not: the adverbial schnell 'quickly' in (10a) does not modify the state of Maria's being in the city, but is an inferred event in her going to the city. The event coercion cannot be applied to the antonym langsam 'slowly', see (10b) (the examples are from Maienborn (2007: 118)):

(10) a. Maria war schnell in der Stadt. Maria was quickly in the town. 
b. ?? Maria war langsam in der Stadt.

Maria was slowly in the town.

If colour state expressions display eventive properties, how close are they to actual events? A test that separates process (and event) expressions from stat(iv)e expressions is the anaphoric happen-test: events happen but states do not (Jackendoff 1983: 170-171). In Estonian, the corresponding verb to happen is juhtuma. As example (11) shows, either colour predicative construction or colour statives are not open to juhtuma-paraphrase:

(11) a. *See, mis juhtus, oli et taevas oli kollane kuu. What happened was that in the sky was yellow moon b. *See, mis juhtus, oli et taevas kollendas kuu.

What happened was that in the sky yellow-ST-PAST-3SG moon

On the distinction between the different types of situations, Pajunen (2001: 121) notes that states usually lack the feature of control entirely. Thus, statives fail to undergo passive alternation (12a) and cannot be formed in the impersonal (12b) or imperative structures (12c):

(12) a. *Kun on kollendatud.

The moon is "appeared yellow by someone" [yellowST-PTC]

b. *Kuud kollendatakse.

The moon is being "appeared yellow by someone" [yellow-ST-IPS]

c. *Kollenda!

Appear yellow! [yellow-ST]

In sum, the tests indicate that the stative colour verbs correspond clearly to the Davidsonian state properties while the colour predicate construction meets distinctly neither Kimian nor Davidsonian state properties as defined by Maienborn. 
However, the central classificator of static and dynamic states in Bach's terms, the (dis)ability to combine with the progressive form (realised in the perception report test) distinguishes the colour expressions from each other. Is the Estonian copular construction exceptional in comparison to e.g. German or Spanish? According to Maienborn (2003, 2005a), in these languages, copula constructions are clear Kimian state expressions. In order to answer this question, a much larger examination of different types of copular structures is required than the scope of the present study. It seems that at least in case of the Estonian stative colour expressions, the temporary-constant (stage-level/ individual-level) opposition has relevance after all.

\section{Colour states in conceptual semantics}

\subsection{Conceptual structure of static and dynamic colour states}

In this section, I will strive for a semantic analysis of the colour states. The stative colour expressions will be investigated according to the conceptual semantics approach. I will refer to the situation expressed by the colour predicative construction as the static state and to the colour stative as the dynamic state.

First, I will briefly explain the basic principles and methodology of the theory that will be adopted for the description of the different types of (colour) states. The conceptual semantics theory is based especially on the work of Ray Jackendoff (1983, 1990, 1997, 2003), developed by Nikanne (1990, 2002, 2008). The basic assumption of conceptual semantics is embodied in the Representational modality hypothesis (Jackendoff 1997), which suggests that linguistic and non-linguistic information is organized in different levels of representation: phonological, syntactic and conceptual. These levels are, in this theory, seen as separate modules with their own primitives and their combination principles. Conceptual representation of a word or lexical conceptual structure is understood as the level of understanding 
linguistic information. Basically, the question this theory asks is what we know when we recognize a word (See e.g. Nikanne 1997, 2008).

According to Jackendoff (1983 and later), the conceptual structure has syntax of its own, consisting of conceptual primitives and rules of combination. At the level of conceptual structure, a sentence is assembled from conceptual categories, such as Event, State, Thing (or Object), Path, Place and Property. Events and States thus represent situation types. The centre of the conceptual structure is the thematic tier expressing causation, change, durability, direction and location. The thematic tier operates with thematic functions (CAUSE, GO, TO, FROM etc.) that select a thematic argument (a theta-role) and/or another function. The conceptual categories can be divided into simple and complex categories: the complex categories are function-argument structures at the event-structure level, while the simple categories are not. For instance, COLOUR belongs to the simple category Property and is not governed by event structure functions but appears in argument positions of such complex categories as SITUATIONS, which are normally built around verbs (see e.g. Nikanne 2000: 80-81.) The lexical entry of the adjective yellow can thus be described as in (13):

(13) $\left[\begin{array}{l}\text { yellow } \\ \text { A } \\ \text { PROPERTY [COLOUR] }]\end{array}\right]$

Since the basis for my analysis will be the tiernet model of conceptual semantics developed by Nikanne (1990, 1997, 2002, 2008), I will continue by presenting the relevant parts of its formal technology. The basis of the well-formed conceptual structure in the tiernet system is a chain of functions, the $f$-chain. The order of the f-chain is not arbitrary: it is based on dependency relations between the functions, determined by three 'positional groups' or thematic zones. Consequently, the direction in the f-chain is always from the causative zone toward the locative zone, from left to right (Nikanne 1990, 1995, 1997). The organi- 
zation of the zones and how the thematic functions and thematic roles are divided within it are illustrated in Table 3, taken from Nikanne (1997: 83):

Table 3. Zones and semantic functions.

\begin{tabular}{lll}
$\begin{array}{l}\text { ZONE } 3 \\
\text { causative zone }\end{array}$ & $\begin{array}{l}\text { ZONE } 2 \\
\text { thematic zone }\end{array}$ & $\begin{array}{l}\text { ZONE 1 } \\
\text { location zone }\end{array}$ \\
\hline CAUSE & GO & AT, ON, IN, \\
LET & BE & UNDER \\
INCH & STAY & TO, TOWARD, \\
& EXT & FROM, VIA, \\
& CONF & AWAY-FROM \\
& MOVE & \\
\hline Agent & Theme & $\begin{array}{l}\text { Location, Goal, Source, } \\
\text { Route }\end{array}$
\end{tabular}

The functions relevant to the analysis of stative expressions are the Zone 2 functions BE and STAY. STAY and BE are dyadic functions that select a theme argument and a place function (IN, ON or AT) indicating the theme's location (cf. Mary stays in the room and Mary is in the room). Both functions STAY and BE reflect a static relationship between a theme and a location but, in contrast to the function BE, STAY does not indicate a permanent situation (about the thematic functions, see e.g. Nikanne 1990: 15-16, 2008). An important difference between STAY and BE thus lies in their temporal structure: the function STAY expresses a temporally related situation, while the BEfunction has nothing to do with time. Nikanne (1990) and Jackendoff (1990) consider the existence of the notion of time to be the crucial difference between states and events in general.

The discussion in section 3 suggests that the distribution of the functions BE and STAY corresponds quite well to the colour states discussed in this article. I thus analyse the colour predicative construction through the (static) thematic function BE (see 14). The stative verb structure passed the eventuality tests and proved to be a true Davidsonian state or dynamic state; therefore, it can be analysed by the "dynamic state function" STAY 
(see 15). Following the co-indexing notation of Nikanne (2000), the subscript indices in (14) and (15) stand for the syntacticoconceptual linking. For example in (14), all elements of conceptual structure marked with superscript indices I correspond to the same superscript indices in syntax ${ }^{11}$. For simplicity's sake, the conceptual arguments in structure (14) are in English.

(14) $\mathrm{Kuu}_{2}$ on kollane $_{3}$

Moon is yellow

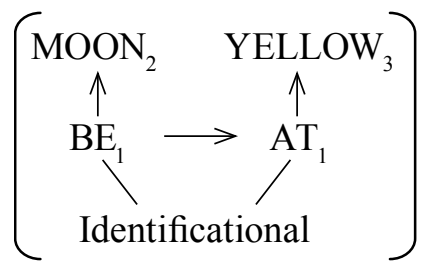

(15) $\mathrm{Kuu}_{2}$ kollendab Moon yellow-ST-3SG

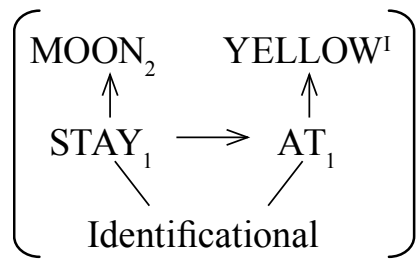

A difference between (14) and (15) is that the argument YELLOW, selected by the place-function AT, is an explicit argument of copula construction and an implicit argument of the stative verb. Following Nikanne's (see e.g. 1997: 87) notation, I mark the implicit argument with the superscript index I in (15).

11 The argument linking is, within the conceptual semantics, not assumed to display a one-to-one correspondence: each major syntactic constituent of a sentence maps onto a conceptual constituent, but not every conceptual constituent necessarily has a syntactic correspondence (see e.g. Jackendoff 1990: 22-27). This is exemplified also in structure (13), where the implicit argument YELLOW has no counterpart in the syntactic structure. 
The structures (14) and (15) include, in addition to the thematic tier description, the semantic field Identificational, concerning the categorisation and ascription of properties in locational terms $^{12}$. Jackendoff (1983: 194) defines the Identificational semantic field in relation to the spatial semantic field, so: Things appear as theme and Thing types and Properties appear as reference objects; being an instance of a category or having a property plays the role of location. Typical of the identificational semantic field is that the NPs mapped to the reference objects occur grammatically as predicate nominals.

Helasvuo (1990: 204-206) notes that the event-function STAY seems to be the central function in the description of the identificational semantic field. However, she questions the status of STAY and its relation to the identificational field because of the ambiguous nature of the temporal dimension: is the time notion really there or should the situation rather be described by the state-function BE? Helasvuo suggests that, in the case of a weak implication of change (as for instance by the predicative adverbials in essive case in Finnish denoting durativity), the function $\mathrm{BE}$ is more appropriate and the temporally restricted situation should rather be described on the temporal tier level. We saw in Section 3.2 that the colour stative verbs are a clear case of Davidsonian (eventive) states and can thus be analysed by the dynamic state function STAY. The colour copula construction appeared to be more ambiguous, although the central Kimian state property is there, which allows us to analyse this construction with BE-function.

We can now return to the discussion of cause-operator in connection with certain stative verbs (based on the observations of Rothmayr 2009) in Section 2. Do colour statives encode cau-

12 The semantic field tier situates events or states on a cognitive background: spatial, possessive, temporal etc. The semantic field treatment in conceptual semantics is based on the Thematic Relations Hypothesis, defined in Jackendoff (1983: 188). The idea of this approach (originally based on the ideas of Gruber 1965) is that different kinds of semantic fields are derived from the spatial field, i.e. the semantics of motion and location is the basis for more abstract concepts. 
sality as the reason for the appearance of the object in a certain (temporary) colour? I do not assume that the colour statives lexicalise causality, even if the implication of a conditioning factor is there. However, these verbs demonstrate an interesting phenomenon regarding the notion of causativity: they can express causation between two states (not between events, as causation often is defined). I will give an example in (17); there will be more examples of causal relationships in connection with colour statives in Section 6.

Consider the elative adjunct construction in connection with the colour stative verb valendama 'to appear white' in (15); the elative adjunct oitest lit. 'from the flowers' expresses the cause for the coloured state expressed in the main sentence kirsid valendavad 'the cherry trees appear white'. In the conceptual structure (17), I use the causative subordinate operator $\mathrm{CS} \uparrow$ (BECAUSE OF) indicating that the adjunct structure is the reason for the situation described in the matrix structure. The adjunct situation is the cause of the situation described in the matrix sentence and is thus within the scope of the subordinate causal operator CS $\uparrow$ (about subordinate causative structures, see Paulsen 2011: 214). Note that the theme argument of the matrix structure (CHERRY TREE) is co-indexed with the place argument of the subordinate structure using the Greek letter $\alpha$ - this is a convention proposed by Jackendoff (1990: 63) for binding a syntactic argument that is mapped to multiple theta-roles.

(17) Kirsid valendavad $_{1}$ oitest $_{3}$ Cherry-PL white-ST-3PL flower-PL-ELA 'Cherry trees appear white because of the flowers on them'

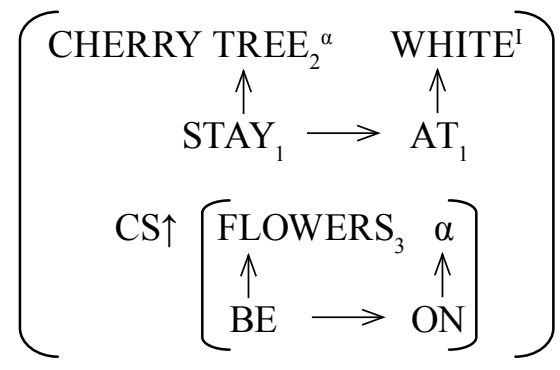




\subsection{Colour verbs anchored to the observer's perspective}

Talking about coloured entities in the environment, the speaker verbalises his or her inner experience as a reaction on an outer stimulus which in turn is a result of a complex processing course. The domain of experience is comprised of such faculties as sensual perception, bodily sensations and feelings, cognitive processes and emotional reactions (Verhoeven 2007). Colour is a visual property perceived by seeing, which implies the presence of a viewer. The observer or experiencer of the visual stimulus is in case of stative colour verbs located outside of the proposition and not marked explicitly as e.g. in verbs look and see.

Using a colour verb, the speaker thus expresses how things look to the observer. Consider the sentences (a) Ta punetab näost 'His face is seen by the colour red [red-ST-3SG]' and (b) Tal on punane nina 'He has a red nose' - in the case of the colour stative verb, the viewer frames the visual image as a state at a particular moment, not a statement about the characteristics of a person, as in (b). How can this be captured in the description of the conceptual structure?

Jackendoff's (1983) representational object theory has added mental representations to the ontology, making it possible to analyse the expressions without a coherent truth-conditional relation to the "real world". Such structures are belief-contexts, expressions involving such verbs as believe, think and imagine or perception verbs (ibid. 237). In the semantic description of the perception verbs, it is possible to operate with the REP-modificator; the predication connected with REP is interpreted as a mental image (related to other Things in the world) (ibid. 222). The representational level is a central semantic aspect in connection with the colour verbs, as the observer depicts something in a specific way. When it comes to visual conceptualization, REP may focus on the components of the visual representation of an entity, its shape represented by the colour. This thus accounts for the possibility of speaking about the visual property COLOUR from the point of view of the observer, how Things appear to 
him/her. Consider an example of the colour stative kollendama 'appear yellow':

(18) $\mathrm{Kuu}_{2}$ kollendab Moon yellow-ST-3SG

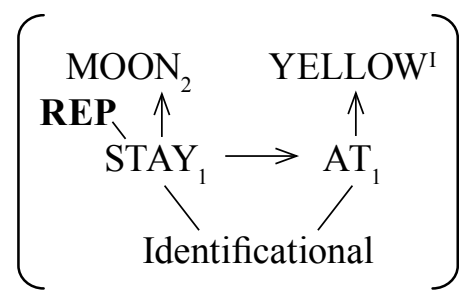

Comparing this to the copula construction Kuu on kollane 'The moon is yellow', we can see that it presents the state of affairs as if the yellow colour was the constant property of the moon, even though our world knowledge says that the exact shade of the moon's appearance to the human eye depends on several occurrences, such as the clearness of the atmosphere, the angle it is viewed from the earth and the sunlight reflecting the moon to us. Therefore, the REP-operator cannot be used in this case. Hence, the REP-modificator in connection with intransitive predicates gives the interpretation that the predication is a mental image and cannot be taken as the basis of inference.

To sum up, I suggest that the lexical conceptual structure of stative colour verbs can be generalised as in (19):

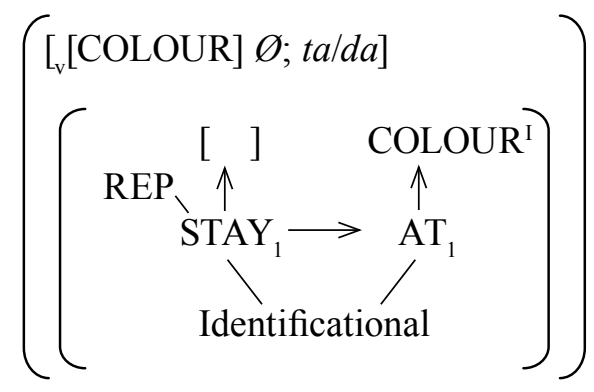




\section{Existential quality of colour expressions}

There is a sentence type characteristic to the copula constructions and colour stative verbs, licensing temporal and locative modifiers, as well as a link to the discourse: the existential clause. In Estonian, the existential clause does not require an expletive subject; the essential elements are the fixed (A)VS word order and the presentative function of the proposition. The clause-initial component of the existential clause is an adverbial of location or time, and the proposition denotes the existence or presence of someone or something, "anchoring" the subject referent to a spatial or temporal frame. (see EKG II: 42.) We can modify the colour expressions that served as the starting point of this study. An example of the colour stative in the existential clause is presented in (20). The colour adjective can occur in the existential clause only in an attributive function (21).

(20) Taevas kollendab kuu. sky-INE yellow-ST-3SG moon

'There is a moon casting a yellowy light in the sky'

(21) Taevas on kollane kuu. sky-INE be-3SG yellow moon

'There is a yellow moon in the sky'

The predicate of existence can be the copula-like verb olema or some intransitive verb. EKG II (42-43) divides the verbs adopting the existential clause type into three groups: (a) existential verbs (olema 'to be', asuma 'to be situated', and esinema 'to occur'), (b) situational verbs that express being in a state, transition from one situation to another or the arising of a situation (paistma 'to appear'; kasvama 'to grow'; sündima 'to be born') and (c) motion verbs (tulema 'come', and saabuma 'to arrive'). The stative verbs thus belong to the miscellaneous class (b) - not existential per se but involving both a descriptive and an abstract existential element. 
In addition to the reverse word order, the existential clause type is exceptional in respect to the subject case, which may be the partitive case. The following rule applies: in existential clauses with negative meaning, the subject always assigns the partitive case; in affirmative clauses, the subject may be in nominative or partitive. The existential clause may also lack the adverbial and the verb may in some cases be transitive; the word order is also not fixed. (EKG II: 43.) The colour statives can have the adverbial both in the initial and post-verbal positions (22a). In order to have an existential quality, these verbs seem to require the full form of the existential clause structure. The subject assigns the nominative case; the partitive subject is not acceptable (consider (22b)), although it is slightly better in plural ${ }^{13}(22 \mathrm{c})$.

(22) a. Kun kollendab taevas. moon yellow-ST-3SG sky-ILL

b. *Taevas kollendab kuud. sky-ILL yellow-ST-3SG moon-PART

c.?Taevas kollendab tähti. sky-ILL yellow-ST-3SG star-PL-PART

If the stative verbs are generally semantically based on the empty copula sentence, do these verbs automatically encode an existential component? The stative colour verbs are all able to appear in (rhematic) VS order and obtain the existential meaning. However, not all statives seem to occur in the existential clause type, as for instance the stative verbs expressing mental states/processes and emotions (see 23a-b). These verbs differ from colour statives in that they encode an animate experiencer.
a. ${ }^{*}$ Koolis
huvitab/häirib/muretseb/rõõmustab
last.
In the school interests/fazes/worries/delights the child.

13 The partitive NP is not regarded as a subject when the verb is in congruence with the subject in plural form (e.g. in Taevas kollendavad tähed 'In the sky yellow-ST-3PL star-PL'). 
b. *Õues pahutseb/kavaldab/vagatseb ema. Outside grouches/is canny/is pious mother.

The existential construction has a contextual dimension: the nominal linked to the theme argument, describing the entity whose existence is under discussion, introduces a novel referent to the discourse. Israeli (1998) notes that the Russian colour verbs ending with sja- convey an existential quality (a state elicited by circumstantial conditions) that "competes" with the descriptive quality of the colour verb. However, the existential sentence type is argued to stand for a specific syntactic structure and the semantic property (the (non-) existence of something) is then seen as misleading (Moro 2006). Whether (and to what extent) there is such a conceptual dichotomy regarding the Estonian copula construction and colour statives is not possible to treat exhaustively in this article.

\section{The case of stative verbs derived from punane 'red'}

In this section, I will take a closer look at the colour statives derived from punane 'red': punetama, punama and punerdama. The observations are based on the examples retrieved from the Fiction Corpus (with a total of about 6 million words) and Newspapers Corpus (the subcorpus of Eesti Ekspress with 7.5 million words) from the Balanced Corpus of Estonian. This study is a qualitative analysis of the salient patterns of these verbs. Firstly, as mentioned in the previous section, a clause type characteristic of colour statives is the existential clause. The distinguishing XVS word order of existential clauses is given in example (24a) and an existential clause with the SVX order is seen in (24b). Example (24c) illustrates the descriptive expressive quality of colour statives, an observer's view of the landscape from a distance. In (24d), the ground is contrasted to the figure, giving a (cold) shade to the figure (rowans) in the centre. 
(24) a. Kui etendusel pärast avastseeni söandasin uuesti pilgu lavale heita, imestasin, et põrandal ei punetanud vereringe.

'When I, after the opening scene of the show, dared to look at the stage, I was surprised there were no blood circles appearing red [red-ST-PTC] on the floor.'

b. /---/ vaid tellisvaremed punetavad võpsikus.

'there are only brick ruins appearing red [red-ST-3PL] in the brush'

c. Taevas roosatas ning mäed punetasid, üksikud pilvetupsud olid värvunud hõbedaseks.

'The sky looked pink and the mountains looked red [redST-PAST-3PL]; a few clouds achieved a silver colour'

d. Ma vaatasin pihlakaid, need punetasid külmalt vastu külma taevast.

'I was watching the rowans; they appeared red [redST-PAST-3PL] coldly against the cold sky.'

The verb punetama 'appear red' seems to be specialised to denote changes in the skin colour caused by changes in the bloodstream and oxygen saturation in the blood that the human eye is able to perceive. The stative punetama focuses on the state after the change, which is seen as an aberrant colour of the skin. The state of the skin colour (typically on the face, parts of the face or neck) thus reflects the state of the health of the person referred to, both unhealthy (see 25) and healthy reddening:

(25) a. Jupiter, tüseduse ja ebatervelt punetavate põskede planeet, liigub sinu tähemärgis, mistõttu peaksid vältima liiga rasvast toitu.

'Jupiter, the planet of corpulence and unhealthy reddening [red-ST-PTC-PL-GEN] cheeks, moves in your astrological sign; therefore, you should avoid high-fat food.'

The constructions encoding the body part possessor as experiencer are recurrent in different types of languages (Ver- 
hoeven 2007). The person part constructions including a colour stative differ from the main experiental constructions (see the examples (26a-b) in that the possessor of the body (parts) is not the experiencer of the bodily senses. The colour verbs mediate the inner mental or emotional state of the described person to the addressee, who interprets the physiological signs that the colour states give rise to. Thus, if someone is clenching something so tight that 'the knuckles look white' as in (27a), the speaker may indicate that the described person is irritated, nervous or excited; the statement that someone's ears appear red (cf 27b) can be a sign of shame or excitement.

(26) a. Mul pea valutab.

'My head aches.'

b. Lapse varbad külmetasid.

'The child's toes were cold'

(27) a. Ta pigistas raamatut nii energiliselt, et sõrmenukid valendasid.

'She clenched the book so vigorously that her knuckles looked white [white-ST-PAST-3PL]

b. Mehe kõrvad punetavad.

'The man's ears look red [red-ST-3PL]

Hence, it is not only verbal expressions that give us a hint of the state of mind of a person - on the basis of facial signs and expressions we determine the mental processes going on in another human being. The colour shades on our faces and facial parts play a significant role in the judgement of the whole interactive situation. The verb punetama is a colour verb that conveys the emotional state of a person, as in example (28a). This verb may also give an indication of the character of the described person, a clue from which the listener/reader can infer something about the personality and habits of the "targeted" person. In this case, the colour has a more constant quality (see e.g. 28b). 
(28) a. Rendiauto nooruke juht vaatas teda üllatunult, keeras pea kohe tagasi ega öelnud midagi. Ainult kõrvad punetasid, lausa lõomasid.

'The young driver of the rental car looked at him with surprise, turned his head back at once and did not say anything. Only his ears looked red [red-ST-PAST-3PL]; they were outright blazing.'

b. Ka tema põskhabe oli nü̈̈d vägevam ja põsed selle kõrval punetasid nii mis kole.

'His sideburns were now mightier and the cheeks next to them looked red [red-ST-PAST-3PL] like hell.'

What explains the emergence of the coloured state? The cause of it is, in the case of colour statives, typically expressed by an adjunct in elative case (compare also to the elative adjunct construction analysed in section 4.1). The elative adjunct may indicate an inner emotional state as the cause of the (red) skin colour (Mees punetas vihast/pettumusest/häbist/uhkusest 'The man looked red [red-ST-PAST-3SG] from anger/disappointment/ shame/proud-ELA', (see (29a)), or external conditions (Mehe põsed punetasid pakasest 'The man's cheeks were red [red-STPAST-3SG] from frost-ELA', see (29b)). However, the elative adjunct does not necessarily indicate the causer; it may also specify the body part of the person that bears the red colour (see 27b).

(29) a. Georgi nägu punetas erutusest ja ta käed klammerdusid toolileeni külge, nii et sõrmeotsad valgeks muutusid. 'Georg's face looked red from excitement and his hands were grabbing the chair so that his knuckles looked white [white-ST-PAST-3PL]

b. Ta punetas näost - mis nad siin ühe araablase tühja pärast jahmerdavad?!

'His face looked red - why are they tearing around because of an Arab?!'

There is an idiomatic expression related to the body part constructions occurring with the verb punetama, nägu punetab peas 'the face appears red on the head' (see (28a). Note that the 
word order of this expression cannot be changed (compare to (30b)), which underlines the fixed idiomatic nature of the phrase.

(30) a. Omal kintsud jämedad kui palgid ja nägu punetab pääs. '[She] has gammons like billets and her face looks red [red-ST-3SG] on the head.'

b. *Peas punetab nägu. 'on the head red-ST-3SG face'

It is striking that the studied colour verbs are only used in the third-person form. Is this the case because of the external observer's presence? The (narrative) text type of the corpus collection obviously sets its boundaries, but this seems to be a striking feature. I have found one example of third-person use of punetama 'appear red' that refers to the appearance of the speaker itself; also this sentence gives the impression that the speaker is looking at him/herself from outside:

(31) Tundsin, et nägu punetab ja kuumab ja on paistes.

'I felt that my face looked red [red-ST-3SG] and it was hot and swollen.'

Finally, it must be noted that the stative variant of punane 'red', punerdama, is quite rare in the corpus; there are only five occurrences in the fiction corpus, all cases of the attributively used participle presence tense form, as in (32):

(32) Suutmata uskuda, õieti teadmata, mida teeb, sirutas ta käe, ning vaatas sõrmeotstel punerdavat verd.

'She could not believe it; without knowing what she was doing, she reached out her hand and watched the blood looking red [red-ST-PTC] on her fingertips'

\section{Conclusions}


The present study aims to elucidate stat(iv)e situations through the example of two kinds of colour expressions: the copula construction with a colour adjective and the stative colour verbs in Estonian. The examination of the stative colour expressions proved that there is a distinction between properties and eventualities. The colour predicative structure was found to correspond both to the notion of Kimian states and Davidsonian states, whereas the colour statives are true Davidsonian eventualities. These expressions can be classified as static states and dynamic states, respectively.

The conceptual structure of both stative situations were analysed as well as the causative relations regarding the conditioning of the colour states. The two types of colour states were analysed by the (atemporal) state function BE and the (temporally bound) event function STAY. The function STAY was analysed as a "dynamic state function", corresponding to the Davidsonian state type. Using the methodology of conceptual semantics, a central semantic element of colour statives was added to the description. The property of colour statives that allows the depiction of the mental image of a coloured shape, connected to the observer's evaluation given at the moment of verbalization, was treated as part of the lexical information of the colour statives.

The results of this study contribute to the knowledge of how our colour experience is structured and how grammatical structures form the visualisation of coloured objects. We can say that the Estonian colour statives are verbs that have an abstract existential component in their meaning, disposing these verbs to the existential construction. This is not the only pattern for the colour statives: in the case of statives derived from punane 'red', special types of inferential constructions can be distinguished, giving hints of the inner (emotional) state of the depicted person or of the external circumstances conditioning the coloured state. Finally, there is the question of the experiencer of a state and the relation of a linguistic structure to the constructed reality. In light of this study, and also other enquiries on stat(iv)e expres- 
sions, we can conclude that the class of states is far from being a "simple" or exhaustively examined phenomenon.

\section{Acknowledgements}

The study was supported by the Estonian Ministry of Education and Research project no SF0050037s10. The article is part of the Estonian Science Foundation grant 8168 and was also supported by the Ministry of Education and Research base funding. I thank the anonymous reviewer for useful comments. This paper has benefitted from the discussion at the conference "Sõna ja mõiste" ("Word and concept"). I am also grateful to Heete Sahkai for her remarks on Estonian progressive. All the flaws are, of course, my own.

\section{Address}

Geda Paulsen

Institute of the Estonian Language

Roosikrantsi 6

10119 Tallinn, Estonia

E-mail: Geda.Paulsen@eki.ee

\section{Abbreviations:}

$\mathbf{C S} \uparrow$ - causative subordinate operator (BECAUSE OF); ELA - elative; GEN - genitive; INF - infinitive; IPS - impersonal; INE - inessive; PAST - past tense; PART - partitive; PL - plural; PTC - participle; REP - the predication in scope of REP is interpreted as a mental image; $\mathbf{S G}$ - singular; $\mathbf{S T}$ - the verbal suffix deriving stative verbs.

\section{References}

EKG II = Erelt, Mati, Reet Kasik, Helle Metslang, Henno Rajandi, Kristiina Ross, Henn Saari, Kaja Tael, and Silvi Vare (1993) Eesti keele grammatika II. Süntaks. Lisa: Kiri. [The grammar of the Estonian language 
II. Syntax.] Tallinn: Eesti Teaduste Akadeemia Keele ja Kirjanduse Instituut.

EKSS $=$ Eesti kirjakeele seletussõnaraamat [The explanatory dictionary of Estonian]. Ed. By Margit Langemets, Mai Tiits, Tiia Valdre, Leidi Veskis, Ülle Viks, and Piret Voll. Tallinn: Estonian Language Foundation, 1988-2007. Available online at $<$ http://www.eki.ee/dict/ekss/ ekss.html >. Acessed on 18.02.2012.

Bach, Emmon (1981) "On time, tense, and aspect: an essay in English metaphysics". In Peter Cole, ed. Radical Pragmatics, 62-81. New York: Academic Press.

Berlin, Brent and Paul Kay (1969) Basic color terms: their universality and evolution. Berkeley: University of California Press.

Davidson, Donald (1967) "The logical form of action sentences". In Donald Davidson (2001) Essays on actions and events. Oxford: Clarendon Press.

Dik, Simon C. (1989) The theory of functional grammar. Dordrecht: Foris.

Dixon, Robert M. W. (2004) "Adjective classes in typological perspective". In Robert M. W. Dixon and Alexandra Y. Aikhenvald, eds. Adjective classes: a cross-linguistic typology, 1-49. Oxford: Oxford University Press.

Dowty, David R. (1979) Word meaning and montague grammar. Dordrecht: Kluwer.

Erelt, Mati (2003) "Structure of Estonian language. Syntax". In Mati Erelt, ed. Estonian language, 9-92. (Linguistica Uralica. Supplementary series, 1.) Tallinn: Estonian Academy Publishers.

Gruber, Jeffrey (1965) Studies in lexical relations. Thesis Ph.D. Massachusetts Institute of Technology. Dept. of Modern Languages. Available at $<$ http://dspace.mit.edu/handle/1721.1/13010 $>$. Accessed on 10.02.2012.

Helasvuo Marja-Liisa (1990) "Identifioiva kenttä". In Pentti Leino, MarjaLiisa Helasvuo, Petri Lauerma, Urpo Nikanne, and Tiina Onikki, eds. Suomen sijajärjestelmä konseptuaalisessa semantiikassa, 200-220. (Kieli, 5.) Helsinki: Department of Finnish, University of Helsinki.

Israeli, Alina (1998) "The speaker as observer: Russian color verbs in -sja and deixis”. Acta Linguistica Hungarica 45, 3-4, 253-270.

Jackendoff, Ray (1983) Semantics and cognition. Cambridge, MA: MIT Press.

Jackendoff, Ray (1990) Semantic structures. Cambridge, MA: MIT Press.

Jackendoff, Ray (1997) The architecture of the language faculty. Cambridge, MA: MIT Press.

Jackendoff, Ray (2003) Foundations of language: brain, meaning, grammar, evolution. Oxford: Oxford University Press. Originally published 2002.

Kasik, Reet (1996) "Denominaalsed olemisverbid eesti keeles". Keel ja Kirjandus 1, 13-18. 
Kim, Jaegwon (1969) "Events and their descriptions: some considerations". In Nicholas Rescher et al., eds. Essays in honor of Carl G. Hempel, 198215. Dordrecht: Reidel.

Koski, Mauno (1983) Värien nimitykset Suomessa ja lähisukukielissä. Helsinki: Suomalaisen kirjallisuuden seura.

Lyons, John (1977) Semantics 2. Cambridge: Cambridge University Press.

Maienborn, Claudia (2003) "Against a Davidsonian Analysis of Copula Sentences". In Makoto Kadowaki and Shigeto Kawahara, eds. NELS 33 Proceedings, 167-186. Amherst: GLSA.

Maienborn, Claudia (2005a) "A discourse-based account of Spanish ser/ estar". Linguistics 43, 1, 155-180.

Maienborn, Claudia (2005b) "On the limits of the Davidsonian approach: the case of copula sentences". Theoretical Linguistics 31, 3, 275-316.

Maienborn, Claudia (2007) "On Davidsonian and Kimian states". In Ileana Comorovski and Klaus von Heusinger, eds. Existence: semantics and syntax, 107-130. Dordrecht: Kluwer.

Metslang, Helle 1993 "Kas eesti keeles on olemas progressiiv?". Keel ja Kirjandus 6, 326-334; 7, 410-416; and 8, 468-476.

Moro, Andrea (2006) "Existential sentences and expletive there". In Martin Everaert and Henk van Riemsdijk, eds. The Blackwell companion to syntax, vol. 2, 210-236. Malden, MA: Blackwell.

Nikanne, Urpo (1990) Zones and tiers. Helsinki: Finnish Literature Society.

Nikanne, Urpo (1997) "Lexical conceptual structure and syntactic arguments". SKY Journal of Linguistics 10, 81-118.

Nikanne, Urpo (2000) "Some restrictions in linguistic expressions of spatial movement". In Emile van der Zee and Urpo Nikanne, eds. Cognitive interfaces: constraints on linking cognitive information, 77-93. New York: Oxford University Press.

Nikanne, Urpo (2002) "Kerrokset ja kytkennät". Available online at $<$ http:// www.abo.fi/fak/fin/kurssit/ KONSEM/>. Accessed on 20.02.2012.

Nikanne, Urpo (2008) “Conceptual semantics". In Jan-Ola Östman and Jef Verschueren in collaboration with Eline Versluys. Handbook of pragmatics. Amsterdam: John Benjamins.

Pajunen, Anneli (2001) Argumenttirakenne. Asiaintilojen luokitus ja verbien käyttäytyminen suomen kielessä. Helsinki: Finnish Literature Society.

Paulsen, Geda (2011) Causation and dominance: a study of Finnish causative verbs expressing social dominance. Åbo: Åbo Akademi University Press. Available at <https://www. doria.fi/handle/10024/67355>. Accessed on 18.02.2012.

Pennanen, Esko (1978) "On verbs derived from adjectives denoting colour in English and in some other languages". Papers from the Conference on General Linguistics, Seili, 24-25 1978, 139-154. Turku: Publications of the Linguistic Association of Finland.

Pustejovsky, James (1991) “The syntax of event structure”. Cognition 41, 47-81. 
Rothmayr, Antonia (2009) Structure of stative verbs. Amsterdam: John Benjamins Publishing Company.

Sutrop, Urmas (1995) “Eesti keele põhivärvinimed”. Keel ja Kirjandus 12, 797-808.

Sutrop, Urmas (2000) "The basic colour terms of Estonian". Trames 4, 1, 143-168.

Vendler, Zeno (1967) "Verbs and times". In Zeno Vendler, ed. Linguistics in philosophy, 97-121. Ithaka, New York: Cornell University Press.

Verhoeven, Elisabeth (2007) Experiential constructions in Yucatec Maya: a typologically based analysis of a functional domain in a Mayan language. Amsterdam: John Benjamins Publishing Company.

\begin{abstract}
Kokkuvõte. Geda Paulsen: Staatilised ja dünaamilised seisundid värvidega seotud seisundiväljendite näitel eesti keeles. Käesolevas artiklis kõrvutatakse eesti keele värviadjektiividest tuletatud seisundiverbide ning värviadjektiivi sisaldava koopulalause näol staatilisi situatsioone. Seisundiverb ja sellele vastav koopulalause on vormiliselt erinevad, kuid tähenduslikult lähedased väljendid, mille erinevust nähakse aspektuaalses (ajutine/püsiv) opositsioonis. Neid seisundiväljendeid analüüsitakse artiklis erinevat tüüpi seisundite ontoloogiliste tunnuste kindlaksmääramiseks väljatöötatud situatsioonidiagnostika abil, mille eesmärk on eristada nn Davidsoni ja Kimi seisundid (vt nt Maienborn 2003). Analüüsi tulemused viitavad sellele, et värviadjektiivi sisaldav koopulalause kaldub Kimi seisunditüübi poole, kuid väljendab ka Davidsoni seisundile omaseid jooni. Värvinimedest tuletatud seisundiverbid aga on selged Davidsoni seisundi tunnuste kandjad. Vaatlusalused värvikeelendid võib niisiis määratleda vastavalt staatilise (Kimi) ja dünaamilise (Davidsoni) seisundi esindajateks. Lisaks situatsioonitunnuste käsitlusele analüüsitakse artiklis värviseisundite kontseptuaalset struktuuri. Kuna värviväljendite puhul on kirjeldatud objekti värv ankurdatud vaatleja tõlgendusega, käsitletakse mentaalset kujutist värviseisundiverbide leksikaalse informatsiooni osana. Vaatluse all on ka mõned värviseisunditega seotud lausekonstruktsioonid ja kontekstiga seotud nähtused.
\end{abstract}

Märksõnad: värviadjektiividest tuletatud seisundiverbid, koopulalause, situatsioonistruktuur, kontseptuaalne semantika, eesti keel 